\title{
A QUEM SERVE A EDUCAÇÃO?
}

\author{
Carlos Rodrigues Brandão (PUC-SP)* \\ https://orcid.org/0000-0001-5449-5991
}

\section{RESUMO}

A partir de algumas civilizações, e recorrendo a tradições conceituais diversas, este artigo é uma reflexão sobre a Educação. Recupera e resume ideias presentes em outros textos do mesmo autor sobre a participação da educação no processo de transformação social e sua relação com a democracia e com o poder. Mediante várias interrogações sobre o papel dos processos educativos em diferentes sociedades, busca-se indagar sobre as distintas práticas de educação, pensadas e vividas, seja como instrumentalização funcional de quem aprende apenas se "instruindo", através de uma capacitação destinada a uma adaptação ao "mundo real do mercado", seja uma educação praticada como formação integral com vistas à transformação de quem aprende através de uma inacabável partilha de saberes destinados à auto, alter e sociotransformação.

Palavras-chave: Educação. Antropologia. Educação popular. Transformação.

\section{ABSTRACT}

\section{WHO SERVES EDUCATION?}

From some civilizations and using different conceptual traditions, this article is a reflection on Education. It recovers and summarizes ideas present in other texts by the same author about the participation of education in the process of social transformation and its relationship with democracy and power. Through various questions about the role of educational processes in different societies, we seek to inquire about the different practices of education, thought and lived, either as a functional instrumentalization of those who learn only by "instructing", through a training aimed at adapting to "real world of the market", is an education practiced as integral formation with a view to the transformation of the learner through an unfinished sharing of knowledge destined for self, alter and sociotransformation.

Keywords: Education. Anthropology. Popular education. Transformation.

\section{RESUMEN}

\section{¿QUIÉN SIRVE A LA EDUCACIÓN?}

Partiendo de algunas civilizaciones y utilizando diferentes tradiciones

* Doutor em Ciências Sociais pela Universidade de São Paulo (USP), Mestre em Antropologia pela Universidade de Brasília (UnB), especialista em Educação e Graduado em Psicologia pela Pontifícia Universidade Católica do Rio de Janeiro (PUC/RJ). Livre docente em Antropologia do Simbolismo pela Universidade Estadual de Campinas (Unicamp), Professor da Pontifícia Universidade Católica de São Paulo (PUC/SP), Professor-pesquisador da Universidade Estadual de Campinas (Unicamp) e Pesquisador do Instituto Paulo Freire (IPF).E-mail: carlosdecaldas@gmail.com 
conceptuales, este artículo es una reflexión sobre la educación. Recupera y resume las ideas presentes en otros textos del mismo autor sobre la participación de la educación en el proceso de transformación social y su relación con la democracia y el poder. A través de varias preguntas sobre el papel de los procesos educativos en diferentes sociedades, buscamos indagar sobre las diferentes prácticas de educación, pensadas y vividas, ya sea como una instrumentalización funcional de aquellos que aprenden solo "instruyéndose", a través de una capacitación dirigida a adaptarse al "mundo real del mercado", o ha una educación practicada como formación integral con miras a la transformación del alumno a través de un intercambio interminable de saberes destinado a lo auto, alter y la socio-transformación. Palabras clave: Educación. Antropología. Educación popular. Transformación.

A construção social da identidade e da mudança na modernidade ocidental é baseada numa equação entre raízes e opções. Esta equação confere ao pensamento moderno um caráter dual: de um lado o pensamento de raízes, do outro, pensamento de opções. 0 pensamento de raízes é o pensamento de tudo aquilo que é profundo, permanente, singular e único, tudo aquilo que dá segurança e consistência; o pensamento das opções é o pensamento de tudo aquilo que é variável, efêmero, substituível e indeterminado do ponto de vista das raízes. (SANTOS, 2014, p. 88). ${ }^{1}$

\section{A quem ela serve, a educação?}

Escrevo aqui como um "ancestral" militante da educação popular, tal como ela foi pensada e posta em prática desde os "anos sessenta" no Brasil e, depois, em toda a América Latina. Escrevo também como um antropólogo, logo, como um alguém que pensa a educação - e tudo o mais que é humano - através da cultura. E, finalmente, escrevo como um professor, desde um já distante agosto de 1967, em Brasília. E começo este escrito com esta breve declaração de procedências para que quem me leia reconheça nelas algumas formas não muito usuais de pensar a educação.

A quem serve a educação?

Esta deveria ser a pergunta original; aquela

1 Se Boaventura quisesse pensar também como um filósofo e, como eu, tivesse o costume de retornar à Grécia antiga sempre que possível, poderia associar o primeiro "pensamento" à filosofia eleática de Parmênides. E a segundo, claro, à de Heráclito. que daria substância a todas as outras. Até mesmo à pergunta: “O que é a educação?". Em algum momento, um pouco mais adiante estarei lembrando que na Grécia Clássica, quando a educação se tornou não apenas uma prática social, mas uma questão filosófica, já então era impossível responder à segunda questão sem, ao mesmo tempo, buscar respostas à primeira.

Comecemos a pensar a educação com uma celebração costumeira em nossas vidas. Quando uma amiga sua faz aniversário, é esperado que além de algumas palavras usuais, entre abraços você dê a ela um presente. Você dá algo a alguém. Mesmo que ela, acolhendo o seu abraço e o seu presente diga, como de praxe, que "não era preciso você se preocupar", ela recebe o seu presente. Embora uma nada diga à outra, é também usualmente esperado que quando seja a sua vez de aniversariar, a sua amiga lhe dê um abraço especial... e um presente. Ela retribui o presente que você deu a ela, e você recebe a dádiva que ela lhe dá.

Essa pequena e costumeira trilogia de afetuosos gestos: dar - receber - retribuir foi tomada por Marcel Mauss como o acontecimento fundador da experiência do ser humano na Terra. ${ }^{2}$ Somos, não apenas afetiva, mas estatutaria-

2 As ideias originais de Marcel Mauss a respeito estão em $O$ ensaio sobre a dádiva, no livro Sociologia e Antropologia. Anos mais tarde, Claude Lévi-Strauss lançou mão das ideias de Mauss, para estabelecer sobre o tabu do incesto e a reciprocidade a própria origem da cultura. Em Nós, os humanos (BRANDÃO, 2016), livro de antropologia dedicado a educadores, trabalho em alguns momentos as ideias de Mauss e as de Claude Lévi-Strauss. 
mente, seres da reciprocidade. Seres enredados em redes e teias de obrigações recíprocas em meio a trocas contínuas de afetos, de ações, de saberes, de bens e até mesmo de pessoas. E é justamente "isto" o que responde, desde as nossas origens ancestrais, por aquilo que, para o bem e o mal, nós nos transformamos ao longo de nossa trajetória na Terra.

Ao final de seu Ensaio sobre a dádiva, no livro Sociologia e Antrologia, Marcel Mauss (1974) lamenta que entre as sociedades primitivas, as arcaicas e as de agora, antigos costumes revestidos de uma generosa e impositiva reciprocidade depressa estejam se perdendo. E depressa estejam sendo substituídos por relações em que a posse e o ganho individuais ou corporativos importam mais do que a troca recíproca e a partilha dos dons entre pessoas e coletivos de pessoas.

Não será difícil imaginarmos que, passando de uma economia de objetos para uma de símbolos (como na "economia das trocas simbólicas" de Pierre Bourdieu), também em qualquer ato relacionado a reciprocidades entre saberes, sentidos e significados algo semelhante aconteça. Assim, em uma situação corriqueira, como em uma conversa entre amigos, ou algo mais coletivo e estruturado, como em uma aula de literatura em uma escola, tudo se passe através de gestos de doação, recepção e resposta. Enfim, ações duais ou coletivizadas de reciprocidades.

Nas situações humanamente ideais alguém diz (ou dá) a sua palavra a um alguém (singular ou plural) que a recebe, ou escuta, ou acolhe. E que em seguida responde, perguntando, declarando etc. Ou também silenciando, por desejo ou por imposição. 0 que acaba sendo também uma outra forma de responder.

Contudo, será a um outro antropólogo, também francês, que deverei recorrer para chegar dos índios a nós, e da troca de dons materiais da economia à troca de palavras, da poesia. $\mathrm{Ou}$ da pedagogia. Em $A$ sociedade contra o Estado, Pierre Clastres (2017) retoma a "obrigação moral" geradora da reciprocidade e, portanto, da possibilidade da sociedade, tal como pensada por Marcel Mauss. E com base em suas pesquisas junto a comunidades indígenas do Paraguai, Clastres (2017) revisita a vigência da reciprocidade através da circulação de dons e contra-dons entre pessoas e coletivos de pessoas, para estabelecer uma ideia que me parece também oportuna para pensarmos a educação.

Já que pessoas, individual ou coletivamente, "se devem" reciprocamente bens, ações, serviços, gestos, palavras, afetos etc., qual seria a "direção da dívida" em cada situação social? Quem deve o que a quem? Ora, em algumas sociedades primitivas é o chefe quem deve a seus subordinados a doação de seus bens, ofertados a outros com dons. Chegar ao comando de uma comunidade obriga quem a chefia a estar continuamente ofertando aos outros os seus bens.

E será preciso que uma sociedade qualquer se torne bastante mais complexa e hierárquica para que a direção da dívida se inverta. Então são os súditos, os comandados, aqueles que devem os seus bens, atos, gestos, serviços e palavras (ou silêncios) a quem os comanda. Os índios do Paraguai recebem de seu líder dons, como dádivas, como presentes que eles não são obrigados a reciprocisar. Entretanto os reis do passado e do presente recebem de seus suseranos impostos, tributos, presentes, sem a obrigação moral ou mesmo política de retribuir. A desigualdade se instala.

Entre o "bem" e o "dom" da economia, e a "palavra" da pedagogia, uma igual equivalência parece evidente. Pierre Clastres (2017) lembrará que assim como deve dons materiais aos seus comandados, o chefe da tribo deve a ela não propriamente a sua palavra pessoal - como opinião, conselho ou ordem -, mas a própria "palavra da tribo", enunciada por ele. 0 "bom chefe" é aquele que não ordena ou aconselha com as suas próprias palavras. Ele é, antes, a pessoa a quem compete enunciar aos outros as palavras que todos conhecem e qualquer um pode "dizer". Tão logo um cacique comece diante do círculo dos outros homens da comunidade a dizer individualmente a sua palavra, 
e não a dos saberes, sentidos e significados da comunidade, ele é deixado de ouvir. E acaba a noite falando sozinho à fogueira acesa e às estrelas.

O que nos leva a antecipar aqui a Grécia, a que deverei retornar mais adiante. Foram de algum modo os guerreiros gregos os criadores originais da palavra-partilha. Ao redor da fogueira, antes ou depois de uma batalha, em um círculo de diferentes igualados. Um círculo em que, como Ulisses, um rei somente reinava se como guerreiro lutava junto com os seus comandados. E somente dizia uma palavra de ordem após ouvir a voz dos outros, quando todos tinham por igual o direito a "dizer a sua palavra", e a tomar decisões através da escolha democrática de uma maioria de e entre iguais. Assim, o saber e o sentido, através da palavra, saltavam do poder de um, ou de alguns, para o direito e o dever de todos. Então a hierarquia das realezas orientais, que desemboca na anomia, dava lugar à isonomia e à sua derivada: a autonomia.

Entre bens e dons propriamente materiais e econômicos, e bens diferenciadamente simbólicos, como a palavra e, através dela, a prece, a poesia e a pedagogia, sabemos que possivelmente a medida mais elementar e a mais singularmente interativa entre todas estaria justamente na resposta a perguntas como: quem pode dizer a palavra? Quem pode, deve ou quem precisa recebê-la como uma ordem, como um mandato, como um ensino, como um conselho, como um saber, ou mesmo como uma pergunta? Quem deve acolher a palavra e cumprir o que foi dito? Quem deve acolhê-la como um saber inquestionável? Quem pode recebê-la, e responder a ela com uma pergunta obrigada? Quem pode recebê-la e responder como uma pergunta livre? Quem pode ouvi-la e responder questionando? Quem pode dialogar livremente com quem enuncia a palavra? Enfim, quando a palavra é uma posse que se impõe? Quando é uma propriedade que se vende? Quando é uma ordem que se impõe? Quando é um ensino que se oferta? Quando é um dom à espera de um retorno recíproco?

\section{A direção da dívida: do dom à palavra, da palavra à educação}

E a educação? Nela e através dela, quem tem que ensinar? Quem deve ensinar? Quem precisa ensinar? Quem quer ensinar? Quem ensina (e aprende) livremente. E também: quem tem que aprender? Quem deve aprender? Quem quer aprender? E a educação, ou "uma educação", a que, ou a quem ela serve?

Retomo uma vez mais à Grécia Clássica. E assim procedo para demonstrar com um exemplo clássico como esta questão é antiga, e como perdura até hoje. Ao longo dos séculos, entre Homero e Sólon a educação grega oscilou entre dois quase extremos, como paideia (daí "pedagogia"), no sentido de "formação da pessoa". Em seus primeiros momentos, a "formação do homem grego" foi compreendida e praticada como um direito da comunidade política - a polis - e como um dever da pessoa destinada e convocada a estudar, a educar-se, a formar-se. E a se formar como um "home educador" para o quê? Para ser um cidadão; um alguém a serviço de sua cidade. Assim, a primeira educação entre os gregos foi originalmente um dever imposto à família responsável por uma criança ou um jovem, como uma obrigação clânica, familiar e individual para com a sua sociedade civil, a sua polis.

Atingir a aretê, através da sequência de aprendizados e praticas da paideia realizava-se por meio de um longo percurso destinado a um se formar e se aperfeiçoar para se realizar, ao longo de uma vida de-quem-estuda-e-aprende, como um ser humano na plenitude de si-mesmo. E o lugar de aferição de tal excelência de realização do belo, do bem e do verdadeiro em uma pessoa educada não era ela própria. Era a sua comunidade, a sua polis. Era a comunidade política à qual ela pertencia e para a qual estava destinada a servir, justamente por haver estudado para tornar-se uma "pessoa cidadã". Um alguém cuja medida do que aprendeu resolviase na qualidade de sua presença e participação entre os negócios da polis, isto é, os deveres devidos a uma cidade-estado. 
Séculos da história grega foram necessários para que essa primeira direção da dívida politica através da pedagogia fosse invertida. Apenas com o advento de uma Grécia não mais centrada em cidades-estado, e após dois ou três milênios de experiências, entre guerras e polêmicas, é que a educação do homem grego alterou a relação entre os seus polos, e passou a ser um dever do Estado e um direito da pessoa.

A plena realização de uma criança ou um jovem, através da formação escolar, tornou-se um direito individual do educando. Um direito dele e de suas comunidades de afiliação: a família, a parentela, o clã. Assim, a educação da Grécia Clássica saltou do coletivo da comunidade política para a individualidade da pessoa pertencente a ela.

Vista por esta ótica, podemos compreender que até os nossos dias uma oposição entre uma educação a serviço de um poder de Estado a que serve a pessoa educada versus uma educação para a realização de um si-mesmo a quem serve o Estado divide ideias, imaginários e ideologias na educação. E não apenas nela. Em uma direção e na outra, um afã de encontrar um ponto de equilíbrio entre uma vocação da educação e a outra tem sido um desafio entre educadores, entre pensadores da educação e entre pensadores da sociedade e da pessoa através da educação. Se aproximarmos este dilema à dualidade de pensamentos de nossa modernidade (e não apenas dela) tal como escrita em nossa primeira epígrafe, veremos que respostas ao que é e a que serve a educação passam por questões bastante mais complexas do que imaginamos a um primeiro olhar.

Se dermos um salto (um longo salto) da Grécia Antiga para a Europa de meados de século XIX e começo do século XX, poderemos lançar outro olhar sobre o dilema perene a respeito dos destinatários, dos usuários, dos serviçais e até mesmo das vítimas de projetos de educação.

Imagino que será difícil encontramos entre nós alguém que, mesmo não trabalhando em uma "instituição pública de ensino", deixe de defender a justa e universal obrigação do poder de Estado de oferecer educação pública, gratuita e de qualidade a todas as pessoas em condições de dela participarem. A defesa da escola pública foi e segue sendo uma "bandeira de luta" de praticamente todas as pessoas direta ou indiretamente vinculadas a alguma atividade pedagógica. Claro, existem exceções e elas são perigosamente crescentes. Contudo elas não pertencem às pessoas com quem usualmente dialogamos. Mesmo assim o seu pensamento hegemônico e privatista deverá comparecer aqui, linhas e páginas mais adiante.

Penso ser importante praticarmos um olhar crítico a respeito do advento da educação pública na modernidade, primeiro na Europa e, depois, em outros continentes. Fora cenários e momentos de uma rara e louvável exceção, desde a sua origem a "educação pública" foi contemporânea do surgimento e de uma conflituada consolidação de antigos e novos estados-nação na Europa. Neles ela instituída e depressa se difundiu entre países submetidos a conflitos internos ou externos. A escola pública emergiu quando guerras entre velhas e novas nações europeias, associadas a conflitos internos entre classes sociais, foram bem mais a regra do que a exceção. E a Prússia, então o mais ditatorial e militarizado dos países europeus, foi pioneira na criação e expansão de redes de escolas públicas.

Escolas públicas e pretensamente laicas aparecem no interior e a serviço de sistemas políticos nacionais fortemente militarizados, entre os armamentos, os exércitos, a propaganda francamente autocentrada em nacionalismos agressivos, e uma educação pensada mais como um direito do Estado e um dever das pessoas do que o contrário. Fora honrosas exceções, em seus momentos de instauração, o modelo mais visível de uma "educação-de-estado" foi o exército e não a sociedade. Mais adiante será a empresa, e não a comunidade.

Assim, uma educação pública de matriz europeia devotou-se, através de suas escolas "abertas a todos", a instruir e formar crianças 
e jovens entregues à tutela de um poder de Estado empenhado em gerar cidadãos letrados, esclarecidos e disciplinados, como homens prontos a "viver e morrer pela Pátria". E mulheres sadias prontas a gerar homens para tais ofícios honrosos.

Na Inglaterra do século XIX, e da revolução industrial, a educação pública tomou um rumo não diverso ao do restante da Europa, mas algo diferenciado. Ali se moderou o "patriotismo militarizado" das outras nações europeias, em favor de uma poderosa e progressista nação "imperial" e imperialista. Na verdade, um "Império Britânico" que desde cedo aprendeu a separar a elite aristocrática - e depois a burguesia florescente - destinada ao ócio, aos negócios, à gestão pública e ao oficialato nas forças armadas, da massa das "pessoas comuns", destinadas a obedecer. Guerrear e trabalhar.

Assim, um acentuado ensino cidadão-militar moderou apenas no essencial um acento militarmente patriótico de suas escolas, para incorporar, sobretudo às "escolas para o povo", aquilo que outros países da Europa tardaram a acrescentar às deles. Algo que depressa os Estados Unidos da América do Norte inovaram e tornaram pragmaticamente o centro do espírito do ensino de suas escolas públicas. Um foco pedagógico centrado sobre a formação de cidadãos competentes-competitivos, direcionados à empresa e à indústria em tempos de paz, e ao exército em tempos de guerra. Algo cedo descoberto como um outro "bom negócio".

Ademais de ser um escritor universalmente conhecido e aclamado, Liev Tolstoi foi também um conde, um integrante da alta aristocracia russa de seu tempo. E nem por isto deixou de ser um crítico feroz da Europa de seu tempo. Criou uma escola para camponeses de sua propriedade rural e dedicou-se, entre o meio e o final e sua vida, a escrever e divulgar cartas e artigos que não lhe valeram o exílio ou a cadeia apenas por sua condição de aristocrata. Eis um momento de um de seus escritos.
Nas mãos das classes dirigentes estão o exército, o dinheiro, as escolas, a religião, a imprensa. Nas escolas, elas atiçam o patriotismo nas crianças com histórias que descrevem o próprio povo como sempre correto e melhor do que todos os outros; nos adultos atiçam este mesmo sentimento com espetáculos, cerimônias, monumentos e uma imprensa patriótica mentirosa; e, o mais importante, atiçam o patriotismo pelo fato de que, ao promover todo o tipo de injustiça e crueldade contra outros povos, despertam neles a hostilidade contra seu próprio povo e depois utilizam essa hostilidade para despertar atitudes hostis em seu próprio povo. (TOLSTOI, 2011, p. 166).

Entre nós, a tradição nefasta de tais "primeiros tempos da educação pública" está até hoje presente e vigente em escolas de vários países da América Latina. Escolas em que crianças e jovens vestidos com os mesmos uniformes iniciam cada dia de aulas entre formaturas de estilo militar em meio a cultos aos eternos "símbolos da Pátria".

E eu pergunto: quando nossas escolas públicas estenderão as suas "aulas de história" dos limites de "minha nação" até todos os territórios ancestrais, antigos e atuais em que os diferentes "povos latino-americanos" construíram e seguem construindo a história real de suas vidas e lutas? Quando nas escolas públicas do Sul da América Latina, a "Guerra do Paraguai" (uma denominação brasileira) será narrada através de um diálogo aberto e franco entre historiadores críticos paraguaios, argentinos, uruguaios, brasileiros e guaranis?

Nós nos acostumamos a ler os escritos de educadores dissidentes e inovadores, entre Comenius, Pestalozzi, Rousseau, Freinet, Tosltoi, Montessori, O'Neill, Rogers, Freire e tantas e tantos outros, como pensadores de uma sempre "outra educação", entre o passado e o presente. E esquecemos que quase sempre era diante da escola pública de suas nações e de seus tempos que eles se colocavam. Entre eles não será difícil entrever como toda uma "outra educação" era proposta em favor de pessoas reais, de destinos solidários, de mundos pacificados, para além do patriotismo que se 
finge de "cidadão" para ser, na verdade, uma versão a mais de um nacionalismo estreito e desumanizante.

A Grécia Clássica condenou e matou Sócrates, sob a acusação de "corromper a juventude e não respeitar os deuses de Atenas". Janusz Korczak morreu na câmara de gás dos nazistas, acompanhado das crianças de sua alternativa casa-escola na Polônia. Educadores insurgentes foram mortos ou marginalizados tanto na Alemanha de Hitler quanto na União Soviética de Stalin. Paulo Freire esteve preso durante a ditadura militar no Brasil, e viveu treze anos exilado na Europa.

E da mesma Europa quero trazer um dos mais contundentes documentos a respeito da educação que eu conheço.

Ao final da Segunda Guerra Mundial, Theodor Adorno, sociólogo e integrante alemão da Escola de Frankfurt, recordando o que foram as escolas públicas de seu país quando dominadas pelo imaginário e o poder dos nazistas, escreveu um dos mais contundentes documentos a respeito de como deveria ser uma educação que jamais voltasse a "formar" crianças e jovens capazes não apenas da violência, quando adultas, mas da barbárie.

Por isto, apesar de todos os argumentos em contrário no plano das teorias sociais, é tão importante do ponto de vista da sociedade que a escola cumpra sua função, ajudando, que se conscientize do pesado legado de representações que carrega consigo. [...] A exigência que Auschwitz não se repita é a primeira de todas para a educação. De tal modo ela precede quaisquer outras que creio não ser possível nem necessário justificá-la. Não consigo entender como até hoje mereceu tão pouca atenção. Justificá-la teria algo de monstruoso em vista de toda monstruosidade ocorrida. Mas a pouca consciência existente em relação a essa exigência e as questões que ela levanta provam que a monstruosidade não calou fundo nas pessoas; sintoma da persistência da possibilidade de que se repita no que depender do estado de consciência e de inconsciência das pessoas. Qualquer debate acerca de metas educacionais carece de significado e importância frente a essa meta: que Auschwitz não se repita. Ela foi a barbárie contra a qual se dirige toda a educação. Fala-se da ameaça de uma regressão à barbárie. Mas não se trata de uma ameaça, pois Auschwitz foi a regressão; a barbárie continuará existindo enquanto persistirem no que têm de fundamental as condições que geram esta regressão. É isto que apavora. (ADORNO, 2000, p. 117).

Pois... a quem serve a educação?

Qual o seu destinatário mais original e essencial? A quem cabe o dever de ofertar a educação e a quem cabe o direito de recebê-la? Ou, ao contrário: quem possui o direito (e o poder) de impor uma educação e a quem compete o dever de recebê-la?

Na Grécia Clássica não havia ainda o que invade e dia a dia hegemoniza nossas sociedade e nossas vidas: o mundo do mercado, tal como o constitui e nos impõe um sistema de gestão da economia e, através dela, da política, que hoje se apresenta como "o único possível e viável na pós-modernidade ${ }^{3 "}$. Hoje, se quisermos pensar as instâncias que organicamente constituem uma formação social, não nos bastaria o desenho simples de uma linha reta, horizontal, em que a Sociedade e o Estado se confundem, como em boa parte das sociedades tribais da Amazônia. E nem nos bastaria a figura de um ângulo reto, em que um dos vetores seria a Sociedade Civil e o outro o Poder de Estado. Deveríamos desenhar um triângulo. Nele, o lado da base deverá representar a Sociedade Civil. Ou seja: Nós. Ou, ainda, aquilo que JeanJacques Rousseau denominou: “o povo soberano". A única instância da Sociedade que possui e pereniza em si-mesma a razão de ser de toda uma Sociedade.

Um dos outros dois lados do triângulo representaria a instância do Poder de Estado. Ali

3 Não devemos esquecer que em seu sentido original, na Grécia Antiga a palavra economia servia a designar a gestão coletiva da cidade e do bem comum. E os gregos reservavam a palavra crematristica para o exercício interesseiro dirigido a gestionar bens pessoais ou corporativos, para acumular riquezas e poder. As duas palavras eram antagônicas, e quem se dedicava ao exercício da segunda, ignorando a primeira, poderia ficar rico, mas seria uma pessoa pouco respeitável. A nossa atualidade capitalista unificou em uma as duas palavras. E hoje economia significa bem mais a crematristica do que a gestão solidária do bem comum. 
estão os "três poderes" que no estado de direito das democracias modernas configuram a esfera da própria sociedade, destinada a, em seu nome e em nome de seus sujeitos, gestionar a "vida pública”. Ou seja, não a do próprio Estado, mas em favor da Sociedade, da qual o Poder de Estado deriva, e à qual ele deve servir. Finalmente, o terceiro lado de nosso improvisado triângulo indicaria o território do Mundo do Mercado.

Em um estado de direito, a esfera, o território, ou o "lado" do mundo dos negócios sequer deveriam se constituir como um domínio próprio. Não deveria exercer dimensão alguma de poder próprio ou delegado. E, tal como o Estado constituído, deveria existir a serviço do bem comum, da sociedade civil, do povo que, afinal, somos todos nós. No entanto, uma expressão comum entre nós revela com exemplar clareza a relação invertida em que vivemos. Ao dizermos que um partido político ou um novo presidente da República "conquistou o governo, mas não poder", estamos revelando a realidade das conjunturas em que vivemos e partilhamos nossas vidas.

Sabemos que sobretudo nas "democracias de baixa-intensidade" - um qualificador caro a Boaventura de Souza Santos -, a direção do exercício da gestão do poder desloca-se de ser um serviço em nome de e em benefício da sociedade civil, e se desloca em direção a servir ao todo ou a setores e grupos do Mundo do Mercado.

0 crescendo de processos de mercantilização de diferentes setores de oferta de serviços de parte do Poder de Estado, entre a saúde, a previdência e a educação, tendem a ser crescentemente deslocados de um dever do Estado para com a Sociedade Civil para se tornarem um poder do Mundo do Mercado sobre a Sociedade Civil, com a anuência do Poder de Estado.

Embora nossas constituições nacionais continuem acentuando a coleção dos nossos direitos civis como a soma dos direitos pessoais e coletivos da Sociedade Civil, assistimos por toda a parte a um duplo processo. Ele vai de uma desqualificação dos serviços públicos destinados a pessoas como você e eu a uma pragmática mercantilização privatista daquilo que deveria ser um direito e uma propriedade coletiva da Sociedade Civil - daí a expressão "bem comum". Algo em que a educação ocupa uma posição central.

Acredito que uma Sociedade Política desvirtua a sua vocação humanizadora e democrática quando exerce em nome do Mundo dos Negócios o controle da esfera da Sociedade Civil, através do crescendo de uma ação centrada na desigualdade social, na exclusão, na restrição da liberdade e, enfim, em uma diferenciada prática hegemônica e colonizadora. Quando, no limite, ela abre mão do que deveriam ser as suas responsabilidades para com a Sociedade Civil, retirando-se da oferta de bens e serviços sociais, que se transformam, no exato momento atual da colonização neoliberal em que vivemos, em práticas mercantis em que direitos se convertem em mercadoria e uma lógica de mercado passa a reger de fato cada vez mais e mais esferas da vida social.

Entre Tosltoi, Adorno e nós, uma mesma crítica à educação, que de fato desde o passado até o momento presente foi e segue sendo praticada, permanece vigente, ainda que com conotações diferenciadas. Tosltoi e Adorno criticavam fortemente o Poder de Estado pelo uso do "público" como um malévolo poder imposto à Sociedade Civil. Saídos do opressivo governo imperial dos soberanos russos, o primeiro, e dos mais do que horrores com que um poder político tornado extremamente militarizado chegou a extremos de desumanidade, o segundo, ambos escreveram suas críticas em períodos em que o controle dos "bens públicos" e da gestão de oferta de serviços - como a educação - ainda não haviam chegado aos extremos de agora.

0 que escreveriam eles se vivessem, como nós, em tempos em que em uma Assembleia Internacional, em algum dos anos finais do século XX, a Organização Mundial do Comércio (a ONU do mundo dos negócios) decretou oficialmente que de então em diante previdência 
social, saúde e educação eram e valiam como... mercadoria?

\section{Entre os vários nomes e as várias vocações da educação}

Agora sim, podemos chegar à nossa segunda pergunta. E ela é também plural. Afinal, o que é a educação? E a pedagogia, o que ela é? E o que elas não são? Aqui na América Latina de agora, o que está sendo a educação, no singular e no plural? Como ela ou elas estão sendo pensadas, propostas e praticadas, entre as suas diferentes alternativas de pensamento e ação?

Ora, mesmo que esse possa não parecer o melhor e nem o mais acadêmico caminho, ao invés de buscar respostas a estas e a outras perguntas em livros e artigos sobre o tema, prefiro inverter a direção de minha busca e fazer aqui uma outra pergunta: quando eu procuro "ver" ao meu redor pessoas praticando o que elas consideram como alguma modalidade de educação, onde, quando e como eu as encontro?

Essa primeira pergunta sugere uma outra, dual: como praticam o que praticam como uma ação pedagógica, e como nominam ou qualificam a educação que praticam as pessoas que vejo ou que reconheço... educando? E podemos pensar ainda em uma outra pergunta, talvez mais de acordo com palavras do momento em que vivemos: em quais cenários, ou em que territórios diferentes, pessoas praticam uma ou algumas das dimensões de uma cultura, a que elas costumam dar o nome de educação?

Reconheço que ousei muitas e complexas perguntas. E devo confessar que neste esboço de escrito deverei apenas me limitar a sugerir alguns rumos e destinações, como quem desenha um mapa, deixando a outros a tarefa de explorar a fundo os seus caminhos e territórios.

Se busco entrever entre as pessoas com quem convivo; as que eu leio e me são de algum modo próximas; e as que eu não conheço pessoalmente, mas leio e estudo os seus escritos, eu acredito que as encontro distribuídas entre alternativas de pensamento-vida-e-trabalho em e entre diferentes territórios sociais e simbólicos do saber, que de uma maneira sumária poderiam ser mapeados improvisada e imprecisamente assim:

a) Algumas pessoas exercem sua vocação de educadoras através de alguma modalidade de ação pedagógica em uma instituição socialmente pública e estatutariamente governamental. No caso do Brasil, instituições públicas federais, estaduais (meu caso) ou municipais. Entre elas, ademais dos ofícios de pesquisa e docência, está envolvida com atividades políticas na esfera da educação ou para além dela. Muitas estão pessoalmente ou coletivamente empenhadas em trabalhar em favor da educação e da escola pública.

b) Por motivos de livre escolha pessoal, ou em razão da carência de oferta de cargos de trabalho em instituições públicas, um número bastante grande e diferenciado de educadoras opta ou aceita trabalhar em instituições privadas de oferta de educação. Instituições que vão desde a educação infantil até universidades. Lembro que no Brasil (e creio que em outros países da América Latina) as instituições de ensino privado, sobretudo no caso das "instituições de educação superior", dividem-se em universidades empresariais e universidades comunitárias. A diferença entre elas é relevante, e nem sempre levada em conta.

c) Algumas pessoas vinculam-se a projetos e ações distribuídas entre as diferentes modalidades de educação - sobretudo de crianças, adolescentes e jovens - entre territórios pedagógicos do que chamarei aqui de educação alternativa. São pessoas vocacionalmente em busca de "uma outra educação", já estabelecida, ou sendo criada "aqui e agora". Raramente vinculadas a sistemas públicos e oficiais de oferta de educação, sob este termo bastante genérico estou alocando aqui 
desde experiências vindas sobretudo da Europa ou dos Estados Unidos. As Escolas Antroposóficas e sua Pedagogia Walldorf constituem a experiência mais conhecida e difundida entre nós. ${ }^{4}$

Devo lembrar ainda recentes iniciativas de criação de cooperativas de educação; de escolas comunitárias, ou ainda de escolas criadas em nome de uma moderada ou mesmo radical transferência do foco da educação do "ensino de quem educa" para a "aprendizagem de quem se educa".

Dentre as pessoas que se afiliam a um difuso "movimento de educação alternativa", reconheço duas vocações polares. Uma é a das pessoas preocupadas com "a formação de meus filhos". Mães e pais adeptos de uma educação especial, altamente qualificada e de ampla liberdade de ação e pensamento, em geral afiliadas a escolas alternativas pagas e caras.

Outra vocação é a das educadoras que se lançam em busca de uma "alternativa de educação" que a partir de experiências pioneiras possa sem ampliada e democraticamente difundida, se possível invadindo o próprio território da educação pública.

Em tempos recentes a pedagogia originada da "Escola da Ponte", em Portugal, derivou no Brasil em experiências equivalentes com um sentido de oferta de uma educação livre e autônoma em escolas de bairros de periferia.

d) Algumas pessoas identificam-se como associadas a alguma modalidade da educação popular. Elas se reconhecem seguidoras das ideias originais de Paulo

4 No Brasil, ademais das escolas antroposóficas existem em alguns estados as "escolas logosóficas". São escolas criadas a partir do pensamento de Carlos Bernardo Gonzáles Pecotche - Raumsol -, um pensador argentino cujas ideias encontraram inúmeros seguidores no Brasil, onde todos os seus livros foram traduzidos. Existe um Sistema Logosófico de Educação, e no Paraná há um Instituto Gonzáles Pecotche. Raumsol criou uma primeira escola logosófica em Córdoba, na Argentina. Ignoro se existe em seu país, tal como o Brasil, uma "Rede de Escolas Logosóficas".
Freire e de outros pioneiros da educação popular no Brasil e na América Latina. Definem-se com frequência como "militantes de causas populares através da educação".

Ao lado de uma afiliação ao ideário de defesa da escola pública, suas praticantes estão quase sempre afiliadas a alguma agremiação de movimentos populares, ou se reconhecem "colocadas a seu serviço político através da educação".

Existem em todo o Continente várias instituições da sociedade civil associadas a alguma prática de educação popular. De igual maneira, movimentos sociais populares com frequência afirmam-se como "de" ou afiliados à educação popular. ${ }^{5}$

Uma característica bastante marcada deverá separar a educação popular, como uma modalidade de prática política através da educação, de outras vocações pedagógicas, algumas delas na verdade bastante próximas a ela. Trata-se de que desde Paulo Freire e desde as experiências pioneiras do começo dos anos 1960 no Brasil, uma marca político-ideológica tende a ser a sua assinatura. Mais adiante comentarei mais a fundo alguns percursos e dilemas da educação popular. Todavia, desde agora é necessário lembrar que ela sempre se pautou por uma adesão insurgente, emancipadora e diferenciadamente socialista aos movimentos sociais de origem e vocação popular.

e) Devo reconhecer aqui um diferenciado conjunto de vocações de educação que possuem como característica essencial serem devotadas ao exercício do ensinar -e-aprender junto a categorias definidas de territórios e sujeitos étnicos, culturais ou sociais.

5 Em uma recente consulta sobre a educação popular realizada pelo Conselho de Educação de Adultos da América Latina (CEAAL), dentre as instituições pesquisadas, 118 reconheceram-se como agremiações afiliadas a movimentos sociais através da educação popular. Eram elas provenientes de praticamente todos os países da América Latina (TORRES CARRILLO, 2012). 
Desde um ponto de vista que certamente deverá ser revisto e aperfeiçoado, reúno aqui vocações pedagógicas que em sua dimensão mais ampla e inclusiva configuram a pedagogia e a educação social. E que entre direções bastante mais especializadas envolvem as diversas alternativas de educação indígena, de educação quilombola (caso brasileiro), ou de outras categorias de pessoas e comunidades étnicas e/ou culturais.

Dada a sua especificidade de destinação, eu deveria colocar também aqui a recente educação do campo, surgida no Brasil dos anos 2000, e fortemente associada a movimentos rurais de luta pela reforma agrária. Se não o faço é pelo fato de que a educação do campo foi instaurada e se apresenta como uma prática definidamente política e vocacionalmente socialista, com predomínio de imaginários, ideologias e propostas de cunho marxista, o que a diferencia bastante de modalidades de educação colocadas aqui. A educação do campo retoma a classe social e a luta de classes como categorias e processos fundadores da análise da sociedade e, especialmente, do capitalismo. E, claro, de sua ação pedagógica. ${ }^{6}$ Entre seus teóricos, militantes e também professores universitários, em seus escritos a educação popular é muito raramente lembrada

f) Acredito ser necessário abrir um cenário simbólico próprio para outras modalidades de prática pedagógica que embora próximas das alternativas do item anterior, delas diferem porque sua ação não se dirige a um território geográfico-

6 Criada a partir de iniciativas de educadores associados ao MST, no Brasil, e também seus militantes e educadores, a educação do campo foi oficialmente instituída no Brasil no começo dos anos 2000, durante vigência de governos nacionais eleitos através do Partido dos Trabalhadores. No excelente e volumoso Dicionário da Educação do Campo (CALDART et al., 2012) estão expostas e debatidas diferentes vocações da educação, com ênfase naquelas de origem teórico-política marxista. social e a seus sujeitos claramente definidos (índios, quilombolas, camponeses), e nem a um "campo social" como uma cidade, mas a uma ampla vocação de uma variante de educação pensada em seu sentido menos restritamente curricular e escolar possível. Seu território de vocação pode ir de um espaço ambiental definido a toda a humanidade.

Coloquemos aqui a Educação para a Paz, a Educação Ambiental, a Educação e Direitos Humanos e outras de semelhante abrangência. Algumas delas "ingressam na escola". Outras permanecem à sua margem e originam movimentos e redes não raro de abrangência internacional. Não raro elas valem mais por suas interações com outras modalidades de educação. Assim é que na América Latina existe um movimento de educação ambiental popular. De igual maneira, acredito ser quase inevitável alguma associação entre: educação social, educação ambiental, educação e direitos humanos, educação e minorias sociais e culturais, educação para a paz, educação prisional, para ficarmos apenas em algumas possível e desejáveis interações.

Talvez também no domínio das práticas pedagógicas estejamos nos abrindo a descobrir que mais valem as teias e redes "entre-nós", que saibamos criar, consolidar e estender, do que o isolamento de cada vocação em seu próprio terreno, e de cada "experiência" em seu próprio e único cenário.

g) Com os antropólogos, deverei chamar aqui de vocações de endoeducação uma modalidade mais ancestral e patrimonial de prática pedagógica do que todas as lembradas acima. E reconheço que a palavra escolhida por mim talvez pudesse ser substituída por uma outra, que com maior sabedoria do que a minha, algumas comunidades indígenas da América Latina estão usando para nominar o que 
pensam e praticam: educação própria. Estejamos prontas a reconhecer a legitimidade e a inteireza de sistemas próprios de construção e partilha de saberes, de sentidos de significados e de valores, de pessoas, povos e culturas que até aqui, de uma forma ou de outra - e com as mais variadas intensões e os mais confessáveis ou inconfessados motivos têm sido tutelados por nós, por nossas agências e por nossas "pedagogias destinadas a".

Reconheçamos que em uma aldeia Ianomâmi da fronteira amazônica entre Brasil e Venezuela, assim como em uma comunidade Aymara dos Andes, e também no Quilombo do Buriti do Meio, nos sertões do norte de Minas Gerais, existem saberes próprios e patrimoniais tão fecundos e acreditáveis, no âmago de suas culturas, quanto os nossos, nas nossas.

E existem mais. Tal como em nossas cidades e universidades, existem "ali" também os seus professores-educadores, os seus mestres e os seus doutores. E mais ainda, "pedagogias próprias". Existem sistemas patrimoniais de partilha e transmissão de saberes não raro menos repressivos e mais efetivos do que os que praticamos em nossas escolas.

Vivemos um afortunado momento de história em que os povos-testemunho estão se lançando em assumir por conta própria - com a nossa ajuda e apoio, quando somos convocados para tanto - a sua própria educação. Algumas iniciativas já foram consolidadas entre comunidades de língua Pano na fronteira entre Brasil, Bolívia e Peru; as primeiras universidades indígenas de povos dos altiplanos colombianos; ou a "universidad campesina" originada de um movimento camponês da Argentina, o MOCASE, serão apenas alguns exemplos de iniciativas e alternativas ao mesmo tempo patrimoniais e pioneiras, que daqui em diante estaremos convocados a reconhecer como nossas interlocutoras "de igual para igual".

\section{Com quem? A favor de quem? Distante de quem? Contra quem?}

Reunidas em um conjunto de dicotomias entre o que impõe o sistema social hegemônico que nós, educadores populares, reconhecemos e frene ao qual nos colocamos, e aquilo que nos desafia a ações críticas, criativas e emancipadoras, desejo a seguir estabelecer aqui não uma reflexão mais acadêmica e completa sobre o que nos une, aproxima ou diferencia. Escolhendo uma outra direção, desejo apenas reconhecer entre nossas convergências, diferenças e divergências, talvez algumas oposições que incompleta e imperfeitamente desenham as nossas identidades e estabelecem o miolo de nossas vocações pedagógicas.

Como sou academicamente originário da Psicologia e escolhi depois ser estudioso e praticante de uma ciência social, é com uma oposição bastante conhecida que prossigo. Em horizonte o mais aberto e impreciso, podemos colocar de um lado práticas terapêuticas e/ou sociais - entre elas a educação - que diferenciadamente buscam soluções pessoais para dilemas, problemas, conflitos sociais.

Algo que na fala de uma educadora poderia ser traduzido assim: "Se logramos formar, desde a infância, pessoas devotadas à solidariedade, à paz, ao acolhimento dos outros, à responsabilidade social, a uma vida pessoal-

7 Tenho participado de encontros, congressos, seminários de educação e ação social junto a comunidades indígenas, comunidades tradicionais (algo muito forte e presente no Brasil) e movimentos populares, em que a diferença entre "nós e eles" é tão reduzida quanto possível. Em uma mesma mesa-redonda sentam-se dois doutores universitários, um xamã indígena e um dirigente de movimento social popular, e somos convocados a dialogar de igual para igual. Os títulos atribuídos pela universidade a nós são colocados lado-a-lado com os títulos com que "eles" se apresentam e conosco dialogam. 
mente integrada e harmoniosa, e socialmente ética e ativamente fecunda, poderemos gerar, em algum tempo de futuro, comunidades, sociedades, nações e até uma humanidade que realizem em sua maior plenitude cenários de vida e de destino igualitários, justos, inclusivos, pacíficos etc."

Em outra direção teremos práticas sociais que também muito diferenciadamente procuram resolver questões pessoais através de ações e transformações sociais. Algo como: "Devemos nos empenhar em frentes de resistência e luta destinadas a transformar as estruturas econômica, políticas, sociais e culturais que preservam todos os males da atualidade, inclusive os que se reproduzem através da educação de tal sistema".

Claro, estabeleci aqui, apenas como um gradiente de alternativas, posições polares. Creio que a maioria das educadoras que conheço, diante dessas duas variantes extremas, optaria por uma posição equidistante, ou pelo menos unilateral em nossa escala de opções. Penso que este seria também o meu caso.

Ainda sem a preocupação de estabelecer uma ou algumas opções de escolha, se quisermos estender a polaridade escrita acima a algumas mais diferenciadas oposições que ora nos unem, ora nos afastam, ora nos antagonizam, poderíamos chegar a este breve e imperfeito desenho de oposições. Algo que em sua polaridade não precisa ser lido e pensado através da aparente radicalidade de suas extremas ou moderadas oposições.

Teremos então:

1. Ações sociais dirigidas à regulação do sistema vigente versus ações sociais de emancipação frente ao sistema hegemônico;

2. Opções de anuncio do "fim da história" versus a negação de histórias únicas e da não-histórias, em nome da criação de pluri-histórias;

3. Motivações teórico-crítico-conformistas centradas em um determinismo de certezas estabelecidas versus motivações críticas e ativamente insurgentes, centradas em princípios de indeterminação e de incertezas transformáveis;

4. Opções pedagógicas centradas na hierarquia, na desigualdade e na homogeneização (a "hierarquia" e a "anomia" dos gregos) versus opções pedagógicas centradas na igualdade entre diferentes, no diálogo e na educação compreendida como construção coletiva e partilhada de saberes (a "isonomia" e a "autonomia" dos gregos).

Alternativas pedagógicas centradas em valores da permanência, da tradição, do estático, do ordenador, do previsível, da reprodução do já existente e regulador versus opções centradas no valor-mudança, na transformação, na mobilidade, na ruptura, na imprevisibilidade, no dinâmico, no assumidamente desordenador e emancipador. Enfim, a oposição entre o monológico e sempre fixo, dirigido a um saber único hegemônico e colonizador, com a reiteração do par desigualdade+uniformidade versus o dialógico e sempre mutável dirigido a pluri-saberes diferenciadamente unificáveis, contra-hegemônicos e liberadores, em direção ao par igualdade+diferenças

Práticas de educação pensadas e vividas como instrumentalização funcional de quem aprende apenas se "instruindo", através de uma capacitação destinada a uma adaptação ao "mundo real do mercado" versus uma educação praticada como formação integral, desequilíbrio e transformação de quem aprende através de uma inacabável partilha de saberes destinados a auto, alter e sociotransformação.

Praticas pedagógicas reguladoras e destinadas à reprodução de democracias de baixa intensidade e apenas representativas versus prática emancipadoras, destinadas a gerar e fortalecer democracias de alta intensidade e ativamente participativas.

Em síntese e recorrendo a palavras e propostas de Boaventura de Souza Santos (2001, 2014), temos oposições entre: monoculturas do saber e do rigor + monoculturas do tempo 
linear + monoculturas da naturalização das diferenças + monoculturas da escala dominante + monoculturas do produtivismo dominantes versus ecologias dos saberes + ecologias das temporalidades + ecologias dos reconhecimentos + ecologias das produtividades solidárias e partilháveis opostas às produções individualistas e utilitárias; sociologia das presenças + monoculturas versus sociologia das ausências + ecologia dos saberes. ${ }^{8}$

\section{A educação popular em diálogo com novas modalidades de ação pedagógica}

Viajemos uma vez mais entre tempos. Em suas origens, à diferença de pedagogias antecedentes dirigidas às classes populares, a educação popular não se realizaria como um serviço suplementar da educação a elas estendido, como terá ocorrido na imensa maioria dos casos quando da implantação de redes públicas de educação.

Em uma outra direção, a educação popular pretendeu colocar-se pedagogicamente a serviço das classes populares e de outras minorias subordinadas, esquecidas ou marginalizadas. E com elas buscou estabelecer um diálogo destinado a que elas próprias aprendessem a se transformar através de um aprendizado que deveria desaguar em pessoas crescentemente "conscientizadas" (palavra-chave nos primeiros escritos de Paulo Freire), e um crescente poder insurgente e democraticamente popular. ${ }^{9}$

8 Não faço referência a um livro único de Boaventura de Souza Santos. Parte do que relembro aqui neste artigo provém de uma mesa redonda de que participamos, na Conferência Arna, em Cartagena de índias, em 2017, e de reuniões mais restritas que reuniram Boaventura e militantes da América Latina.

9 Eis como Tomaz Tadeu da Silva (2000, p. 48, grifo do autor), que não se reconhece como um "educador popular", define educação popular: "Educação Popular - Refere-se a uma gama ampla de atividades educacionais cujo objetivo é estimular a participação política de grupos subalternos na transformação das condições opressivas de sua existência social. Em muitos casos, as atividades de 'educação popular' visam o desenvolvimento de habilidades básicas como a leitura e a escrita, consideradas como essenciais para uma participação política e social mais ativa. em geral, segundo
Um poder paulatinamente transformador, derivado de pessoas que individual e coletivamente viessem a aprender, a partir e através de si-mesmas a: viver a sua vida, recriar o seu destino, pensar com a sua própria mente, aprender a sua verdade, dizer a sua palavra, partilhar a sua luta, transformar o seu mundo, escrever a sua história.

Com diferentes assinaturas e partilhando um leque aberto, mas não muito amplo, de ideologias políticas e de propostas pedagógicas, a educação popular almejava realizar-se sempre que uma crítica individual e coletiva de vocação emancipatória, diante de uma cultura política e de um sistema pedagógico hegemônico dela derivada, associava-se a um projeto originado das classes populares, ou em um estreito diálogo com elas. Eis um projeto pedagógico que idealizou repensar a educação como cultura, a cultura como política e a política como transformação social humanizadora.

A educação popular buscou encontrar na prática do diálogo não somente uma metodologia pragmática de ação pedagógica. 0 diálogo sempre pretendeu ser, nela e através dela, o começo e o final de todo o acontecer do ensinar-a-aprender. Podemos então retornar às primeiras linhas deste escrito e relacionar as críticas antropológicas de Pierre Clastres (ele mesmo um leitor atento de Étienne de La Boétie (2017) e de seu livro Discurso da servidão voluntária) e Paulo Freire (2014).

Todo o acontecer didático da educação popular centrava-se em uma absoluta circularidade da palavra, a partir do suposto de que entre pessoas e culturas todo o sujeito, individual ou coletivo, é uma fonte original de seu próprio e inquestionável saber. Saberes em relação são

a teorização de Paulo Freire, busca-se utilizar métodos pedagógicos - como o método dialógico, por exemplo que não reproduzam, eles próprios, relações sociais de dominação."

Chama atenção que um livro que pretende ser um "vocabulário" crítico e atualizador, entre tantas modalidades de pedagogias e de educações, ele apenas escreva sobre a "educação bancária", como um termo crítico criado por Paulo Freire, educação libertadora (também denominada de educação emancipadora e educação popular). 
culturalmente diferentes, sem poderem ser academicamente reconhecidos como desiguais. A substituição da arquitetura linear da "sala de aula" pelo "círculo de cultura" desenharia uma nova geometria não apenas espacial no acontecer da educação.

Em suas formas mais radicais, a sua "palavra de ordem" seria uma quase inicial "desordem pedagógica", centrada na ideia de que com um mínimo de propostas de base, tudo o que se realiza como e através da educação popular parte de um encontro diferenciadamente igualitário de e entre saberes e significados. Desde uma "turma de alfabetizandos" até uma instituição ampla de criação de uma "proposta de educação popular", o que se almejava era a constituição e a consolidação de coletivos igualados e igualitários tanto quanto possível, em sua vocação de pensar, de dizer e de decidir.

A educação popular de vocação humanista possuiu sempre, ao mesmo tempo, a sua força e a sua fraqueza na radicalidade de uma pedagogia centrada em um diálogo entre pessoas, entre culturas e entre classes sociais, na construção de cada momento e do todo do acontecer da educação.

Sua força, porque ela partiu do princípio de que toda a prática pedagógica dirigida à formação de pessoas autônimas, críticas, criativas e insurgentes somente pode ser realizada por meio de uma experiência de encontro entre sujeitos sociais culturalmente diferentes quanto aos seus saberes, e socialmente igualados quanto aos seus direitos-deveres. Sua fraqueza, porque evitando educar através de metodologias prontas-e-acabadas, entre saberes empacotados, ou doutrinárias palavras-de-ordem, o educador popular poderia saber de onde estaria partindo, mas dificilmente poderia prever aonde iria chegar. Estudos mais aprofundados do que este poderiam estabelecer os termos da diferença entre a educação popular de "vocação freireana" e seus fundamentos dialógicos, e as propostas contemporâneas de projetos pedagógicos de uma educação dialética, dos educadores marxistas.
Falei até aqui de projetos e imaginários dos anos 1960, que eu mesmo vivi intensamente. Viajemos ao presente. Estamos hoje longe dos "tempos fundadores" da educação popular. Devemos levar em conta que mesmo preservando ainda a essência "das ideias de Freire", as pessoas e os coletivos praticantes de alguma dentre as modalidades da educação popular reconhecem que agora "os tempos são outros".

Elas estão certas ao reconhecerem também que em face a alguns acontecimentos de dimensão internacional, latino-americana e nacional, não apenas conjunturas de ação, mas até mesmo fundamentos e horizontes da gestão social da sociedade, da cultura, da política, do saber, da educação e, especificamente, da educação popular foram e seguem sendo inevitavelmente reconceitualizados.

E a expressão utilizada por alguns educadores populares da atualidade é a "refundamentação da educação popular".

A refundamentação está associada a múltiplos fatores, como o esgotamento dos referentes discursivos a respeito da pluralização de práticas e atores da Educação popular, a crise do socialismo histórico e a atração exercida por novas colocações teóricas provenientes das ciências sociais; "desde mediados dos oitenta começamos a sentir uma certa insatisfação a respeito dos discursos que orientavam as nossas experiências, eles nos pareciam limitados para dar conta do que estávamos fazendo; os referentes teóricos com que interpretávamos a realidade, orientávamos os projetos e compreendíamos os sujeitos que os protagonizavam não expressavam tudo o que queríamos dizer ou não correspondiam à realidade sobre a qual estávamos atuando. (CARRILLO, 2012, p. 77-78).

Lembremos que mesmo a partir de Paulo Freire em seus últimos escritos, a educação popular abre-se a um diálogo com outras modalidades de ação social. E nisto reconheçamos que ela recupera em boa medida a tradição original vinda dos movimentos de cultura popular dos anos 1960 no Brasil ${ }^{10}$. Tempos de antes

10 No começo dos anos 1960, o que nos unia e congregava em frentes de luta popular não era a educação popular, cujo próprio termo surgiu bem depois. Era a "cultura popular", pensada não como uma categoria de antropólogos, mas 
revisitados agora, quando pedagogia-e-educação eram pensadas como uma dimensão da cultura, e eram vividas através de um diálogo entre multi-interações e contribuições provenientes de pluri-diversas teorias e propostas das ciências sociais e de ramos humanistas da filosofia de outras ciências e das artes.

De então para cá, por toda a parte entre o Pacífico e o Atlântico surgiram novos atores socais, habitantes de antigos e novos territórios de vida, de trabalho e de saberes. Eles emergiram de um ajustamento a novos tempos e a novas frentes de resistência, resiliência e insurgência.

Esse plural acontecimento se associou ao advento de algumas modalidades e vocações da educação chegadas à América Latina sobretudo após os anos 1970. Surgiram então entre nós novas vocações da educação, inexistentes ou incipientes ao tempo das origens da educação popular. Inovações pedagógicas que eu mesmo combati em alguns dos meus escritos antigos, acusando-as de serem apenas novas "invasões simbólicas do imperialismo".

As mesmas que nós, educadores populares de antes e de depois do movimento de refundamentação, acolhemos como novas e necessárias alternativas pedagógicas. Ações culturais através da educação que, desde quando associadas a posturas e vocações emancipadoras, mais se somam do que competem com a educação popular original.

Assim a educação ambiental (sobre a qual muito escrevi a partir dos anos 1980-1990), a educação para a paz (idem), a educação e direitos humanos (idem), as pedagogias dirigidas a comunidades tradicionais e comunidades éticas (indígenas, quilombolas etc.) e, mais tarde, a educação social e a pedagogia social. E em uma direção definidamente mais "à esquerda", a

como uma ação política de vocação emancipadora que se realizava através de uma interação entre diferentes atores culturais vindos seja da academia, seja do meio das artes, seja de comunidades e movimentos populares. Uma reunião relevante de documentos da época (inclusive da primeira equipe nordestina de Paulo Freire) está no livro Cultura popular e educação popular: memória dos anos sessenta (FÁVERO, 1981). educação do campo dos movimentos populares rurais do Brasil, assim como as experiências reveladoras de projetos pedagógicos de movimentos insurgentes, como os zapatistas, do México.

Não devemos esquecer que uma redemocratização relativa de países da América Latina, associada a um ainda incipiente mas esperançoso empoderamento de movimentos populares, foram também fatores que forçaram a educação popular a se colocar como uma diferenciada instância de apoio político-pedagógico a ações educativas presentes e ativas nos/dos agora vários e diferenciados movimentos populares sociais, culturais, étnicos etc.

Assim, uma inevitável e oportuna abertura em múltiplas direções, e em diálogo com diversos atores sociais, levou a educação popular a migrar de uma exclusiva ou prioritária "leitura classista ortodoxa da sociedade em direção à incorporação de outras perspectivas e categorias analíticas como hegemonia, movimentos sociais, sociedade civil e sujeitos sociais" (TORRES CARRILLO, 2012, p. 78).

Assim, a difícil categoria "povo" passou a receber diversos e, não raro, divergentes sentidos entre educadores populares. Relembro uma vez mais que este é também o momento em que, sobretudo em países pluriétnicos e culturais, vários atores étnicos, culturais e sociais secularmente silenciados fizeram-se crescentemente presentes. E, como lembrei já neste documento, eles obrigaram a própria educação - inclusive as originadas de políticas públicas - a uma revisão de seus imaginários e de seus conteúdos pedagógicos.

E quase sempre são os educadores populares das nações mais multiétnicas e culturais os mais sensíveis a fazer interagirem diferentes sistemas de conhecimento, assim como a incorporá-los substantivamente ao círculo dos saberes, sentidos, significados, sensibilidades e sociabilidades de "outros povos e de outras culturas".

Uma pedagogia "conscientizadora e politizadora", destinada em seu horizonte a transformações radicais da sociedade através de 
uma conquista popular do poder, tende hoje a ser relativizada e repensada no interior de um campo de diferenças entre os diversos contextos sociais. Reconheçamos que para a maior parte dos educadores populares o povo, no sentido original de classe-para-si, segue sendo seja "o" ou, no limite, "um" sujeito protagônico nos processos de luta e mudança social. Entretanto estejamos atentos a que presenciamos um alargamento do sentido político das próprias transformações de seus horizontes.

Sensível a um diálogo com vertentes de pensamento teórico de construção do conhecimento e de suas derivações para a educação, como variantes fundadas em autores que, não raro, provêm mais da física quântica e da biologia do que da economia e da política, educadores populares tendem agora a também abrir-se para acolher novas compreensões de fundo "holístico", "multicultural", "integrativo-interativo" e dialogicamente "transdisciplinar".

Essa derivação inevitável, ao ver de alguns, desloca uma primazia da questão social de um plano socioeconômico em direção a compreensões mais totalizadoras, não apenas do acontecer humano, mas também da complexidade da sociedade. Outros, como Boaventura de Souza Santos, lembram que transformações sociais e epistemológicas dificilmente acontecem, se não ocorrerem juntas e em franca e insurgente interação.

Entre educadores populares algumas questões relacionadas á individualidade, á identidade, à afetividade, e a uma nova conectividade centrada em dimensões que chegam a submeter o racional ao afetivo, tendem a constituir a cada dia o próprio centro de suas reflexões e construções teóricas. E, por consequência, também das pautas e linhas de direção de uma educação que somente pode ser "popular" se for popularmente sensível, e totalizantemente humanizadora.

Estejamos atentas a que uma persistente crise de buscas de um modelo histórico com o horizonte de sociedade situada "para além do mundo capitalista" poderia estar exercendo junto a educadoras do presente e do futuro próximo uma lastimável - e inevitável, ao ver de algumas pessoas - descrença na viabilidade de transformação social em direção a um outro modelo de poder, saber e sociedade.

Em termos caros a Boaventura de Souza Santos $(2001,2014)$, isto representaria o abandono de uma vocação "emancipadora" do sistema capitalista, em direção a projetos e ações sociais apenas "reguladoras" de tal sistema social de poder e de saber. Estou entre aquelas e aqueles que acreditam que para além dos estreitos socialismos já nacionalmente experimentados e, sobretudo, diante do desafio do fortalecimento globalizante do capital internacional, o nosso horizonte de afeto, pensamento e prática deverá, mais agora do que antes, centrar-se na construção de formas alternativas e diferenciadas de sociedades solidárias-socialistas. Se "um outro mundo possível" não é viável, em nome do que eu estaria nesta tarde de março escrevendo isto?

Estejamos atentos a uma variação danosa de vocações da educação, quando elas possam deixar-se levar pela tentação de abrir mão de ideias e ações devotadas a frentes de luta pelo advento de um mundo que finalmente desloque o eixo de poder de transformação do presente e de gestação e gestão do futuro, do mercado e do capital para a vida, para o ser humano e para uma sociedade de plena realização dela e dele.

\section{Entre o que muda, o que permanece?}

Desejo encerrar este escrito com pensamentos voltados ao que acredito que permaneça, entre o que muda e se transforma ao longo dos anos e das décadas. Assim, se sonhamos unificar o que entre os "anos sessenta" e "os dias de agora" permanece como uma sequência de fundamentos e de crenças naquilo que nos move a seguir adiante, sobre que pilares e que valores de pensamento e de ação através de modalidades da educação podemos dialogar e agir? 
O primeiro deles deverá ter uma crença inabalável na vocação do destino da pessoa humana. A confiança de que, apesar de tudo o que vivemos "agora", há um presente a confrontar e um futuro a construir a partir de pessoas como Você e Eu, e em nosso nome. Qualquer que seja o estilo de um governo e a vocação de uma sociedade, a pessoa humana é sempre e irredutivelmente o seu sujeito e a sua razão de ser. A pessoa de cada uma e cada um de nós constitui um valor irredutível em si-mesma. Assim, todos os projetos e todas as políticas sociais devem encontrar cada pessoa e em todas as pessoas de um povo, ou de uma nação, os seus destinatários primeiros e essenciais.

Quem quer que seja, qualquer ser humano é em si-mesmo, e sem mediações, o ponto de origem, o valor de sentido e o destinatário de uma educação vocacionada não a apenas "capacitar o indivíduo" para o-mercado, mas "formar a pessoa" destinada à partilha solidária de e em uma plena vida social.

Um segundo valor. Devemos persistir em pensar e praticar uma educação centrada no valor e no primado da pessoa consciente $e$ cooperativa, diante do avanço de imaginários hegemônicos que edificam e consolidam o primado do poder do mercado do capital como o território central das relações sociais, na mesma medida em que estabelecem como seu ator central o indivíduo competente e competitivo.

Um terceiro valor. Mantenhamos viva a crença em nós próprios e em nossa vocação como educadores. Confiemos no que somos, e no que sempre podemos fazer para mudar nossas cabeças e destinos, e para transformar o mundo em que vivemos. Sigamos, sobretudo quando estamos "remando contra a corrente", acreditando em um dos fundamentos de educação emancipadora de mentes e sociedades: a crença substantiva em nós, em nós-mesmos e no "entre-nós": o território de encontros e diálogos que solidária e ativamente criamos quando nos unimos.

Não somos destinados a nos educarmos para nos subordinarmos a uma ordem social pré-existente, imposta a nós e colonizadora de nossos saberes, de nossos significados, de nossas escolhas e de nossas ações sociais. Mutuamente nos ensinamos-e-aprendemos para sermos, em cada pessoa e em nossas autônomas e solidárias coletividades, os agentes de transformação de nossas vidas e de nossos mundos de vida.

Para além de uma educação humanista em suas versões mais tradicionais, aprendamos a crer e praticar uma vocação da educação que não apenas objetive "formar pessoas em sua eminente dignidade", como passivos senhores de direitos e sujeitos de deveres sociais. Pensemos em algo além. Saibamos educar para formar pessoas e coletividades que se proponham a, crítica e criativamente, tornarem-se mulheres e homens ativamente inconformados. E, portanto, mulheres e homens participantes de processos crescentes e interconectados de emancipação social.

Contra todos os falsos teóricos e "profetas" que em nome do primado do mercado anunciam a morte da pessoa como ser-de-sociedade, e o "fim da história", juntamente com a premissa de que o "modelo capitalista" veio a ser o único sistema humana e socialmente viável, devemos preservar e ascender a nossa crença na História como algo que vivemos, construímos e escrevemos. Uma realista e esperançosa História com um sentido convergente, emancipador, personalizante, socializante e espiritualizante.

A despeito de todas as teorias que acreditam ou apostam no fim das ideologias de transformação de pessoas e de mundos sociais, devemos confiar em que nós somos não somente seres "na história" ou "da história", mas autores-atores coparticipantes de cada momento de construção de nosso "tempo na e da História". Sejamos aqueles e aquelas a quem compete não apenas "seguir o curso da história”, ou simplesmente dedicar-se a estudá-la e criar boas "narrativas" a seu real ou ilusório respeito, mas as pessoas detinadas a vivê-la como a mais difícil experiência coletiva a ser desfiada e construída: a nossa História. 
A afirmação da vocação histórica a uma perene transformação sempre mais humanizadora da vida e da sociedade humana permanece como o "sinal de nascença" e como a assinatura de identidade de todas as modalidades de uma educação emancipadora centrada na individualidade da pessoa e em coletivos culturais e sociais de e entre pessoas.

Saibamos acreditar que pelo Mundo inteiro e em cada local onde vivemos, cabe a cada um, a cada uma de nós, e mais às nossas pequenas comunidades utópicas, e ainda às nossas redes espalhadas por todo o Planeta Terra, e à multidão de pessoas provenientes sobretudo dos povos originários e dos excluidos da Terra, a vocação de tornar real a construção de um outro "mundo possível", como bradamos em nossas caminhadas pelas ruas, em nossos Fóruns Sociais Mundiais.

Acreditemos em nossa vocação destinada a uma permanente e irreversível humanização. Paulo Freire gostava de iniciar algumas de suas falas e escritos com a lembrança de que somos seres inacabados; seres inconclusos. E, assim sendo, a contraparte deste suposto será o fato de que somos seres perenemente "acabáveis"; aperfeiçoáveis; ilimitadamente capazes de nos recriarmos a partir de nós-mesmos, e para além de nós-mesmos.

Existirá um critério absoluto para determinar a qualidade de uma mudança ou transformação social? Sim: ela deverá ser sempre mais humanizante e humanizadora. Deverá representar sempre, e de maneira irreversível, um acréscimo de valor humano ao humano. Um aumento de condições através das quais as pessoas - e todas as pessoas - possam viver, a cada dia mais, uma vida plena e feliz. Isto é, uma vida de qualidade: criativa, livre, corresponsável e solidariamente partilhada em uma sociedade justa, democrática, igualitária, multicultural, não excludente e aberta à constante mudança.

Frente a uma invasão crescente de "programas" empacotados e de sutis colonizações de sentimentos e de mentes, segundo padrões pré-fabricados provenientes de agências de regulação do sistema capitalista, devemos crer no valor e no do poder do saber original que habita o coração e a mente de toda e qualquer pessoa. Crer que cada pessoa, quem quer que seja, é em si-mesma uma fonte original, preciosa e irrepetível se seu próprio saber.

Saibamos recriar a confiança na vocação humana ao diálogo, à partilha, à troca de nossos dons, à solidariedade, à gratuidade, à reciprocidade, enfim. Lutemos por acreditar em tal vocação como o fundamento do que nos faz sermos seres humanos; seres conectivos, sujeitos recíprocos e, portanto, autores de nosso aprender-a-saber.

Como educadores, saibamos aprender que não somos "humanos" porque somos "racionais", ou porque somos "seres políticos", como em Aristóteles. Somos humanos porque somos "seres aprendentes". Seres sempre aprendentes. Seres devotados à perene aventura do aprender.

Quem quer que sejam as pessoas, a sua verdadeira vocação será sempre a abertura ao encontro com a pessoa-do-outro no diálogo entre seres iguais, livres e responsáveis por si-mesmos, pelos outros e por seus mundos de vida e de trabalho. Todo o saber, todo o aprendizado e toda a ação social entre pessoas devem realizar-se como vivências interpessoais e culturais de e entre diálogos. E o fundamento do diálogo entre as pessoas não é outro senão o amor.

Não somos apenas mentes que adquirem e acumulam informações e conhecimentos para permanecermos como sempre fomos. Somos seres que transformam o que aprendem e conhecem em formas pessoais e dialógicas de consciência.

A formação de espíritos autônomos entre mentes críticas, criativas e amorosamente dialógicas é a razão de ser de todo o aprendizado, qualquer que seja uma específica alternativa pedagógica. E esta vocação de aprendizado deveria constituir-se como a razão de ser da educação. 
Pessoas não aprendem apenas para serem "capacitadas", instrumentalizas ou mesmo "recicladas" através da mera informação. Pessoas aprendem para conhecerem. E pessoas aprendem não apenas para acumularem conhecimentos. Aprendem - e deverão estar "sempre aprendendo" - para continuamente processarem saberes ativamente adquiridos como reconhecimento pessoal e interativo de si-mesmas, dos outros e do mundo. Conheço quando faço parte do que é conhecido. Conheço conscientemente quando penso por conta própria e responsavelmente qual o sentido humano e humanizador daquilo que estou conhecendo.

Em interação com outras práticas e processos emancipatórios, a educação deve pretender ser, sem receios, uma alternativa efetiva de poder. Acreditemos que o poder emancipador da educação será possivelmente o mais efetivo e persistente entre todas as práticas sociais emancipatórias.

Pensemos que a tarefa do educador não será apenas o aprimorar pessoas através do conhecimento e da sensibilidade. Para além deste propósito, cabe a ele participar de ações que transformem pessoas, em e entre as suas consciências, os seus afetos e as suas ações, através da inter-troca e da mútua construção de novos saberes, sentidos, significados e vocações de sociabilidade.

Toda a educação sonha uma pessoa! Algumas vezes a sonha como um pesadelo, como quando os nazistas do passado e os nossos ditadores do presente imaginaram escolas que, como fábricas, produzissem autômatos, menos do que seres humanos. Todavia, na mais das vezes a educação sonha um Ser Humano. Entre Platão e Paulo Freire haverá quem acredita que se uma pedra de mármore pode se transformar em uma obra de arte, por que não uma criança? Por que não uma pessoa humana?

Sonhamos também, para além da realização da plenitude de si-mesma em cada pessoa, com um mundo de vidas em que afinal possamos ser seres do dom e da partilha, e não seres do ga- nho e da ganância. E uma diferença substantiva entre as propostas e os processos dos diferentes projetos de criação de pessoas através do ofício de educar está na maneira como cada um dos ideários pedagógicos pensa e faz interagirem estas perguntas fundadoras que os gregos e outros povos do passado nos deixaram: que tipo de mundo criar, manter ou transformar? Como e através de quem? Que pessoas podem, e como poderiam realizar isto? Qual o lugar e o alcance da educação em "tudo isto?"

A busca de respostas a essas e outras perguntas em geral são deixadas às pesquisas e aos pensamentos de filósofos ou de pensadores teóricos da educação e de ciências e outros territórios afins. Sim, talvez sejam pensamentos que cabem a eles. Contudo, somente a eles? Ou também e substantivamente a nós, pessoas devotadas à educação como habitantes daquilo que chamamos no Brasil de "o chão da escola"? Da escola ou de outros territórios do saber e do sentido, em que, entre as nossas diferenças e convergências, nós nos distribuímos entre inúmeras e crescentes "tribos" de praticantes da vocação de aprender para em seguida ensinar.

Quero convocar aqui um militante das causas humanas e populares que conheci há 57 anos, quando éramos ainda estudantes e "militantes estudantis". Ele era desde então e segue sendo um amigo e um mestre. Aprendo ao longo dos anos sempre um pouco mais de algum saber precioso, seja quando estou com ele entre nossas caminhadas, seja quando leio.

Que Marcos Arruda (2009, p. 334) nos ajude a encerrar este escrito.

A educação visa a aprendizagem de 'caminhar no fio da navalha' na relação comigo próprio, com o Outro, com a natureza e com a sociedade e a humanidade. A educação visa o empoderamento da aceitação e do empoderamento do Outro, a partir de assumir o desafio de meu próprio empoderamento para o meu próprio desenvolvimento enquanto pessoa e coletividade. Sem tornar-me eu próprio sujeito de meu desenvolvimento individual e coletivo, não posso aceitar, acolher e colaborar com o empoderamento do Outro como sujeito de seu próprio desenvolvimento individual e coletivo. Nem posso estar 
autônoma e amorosamente conectado com 'a teia da via e do mistério do Universo'. [...] Educar é ensinar a conviver com o mistério do amor; é ensinar a caminhar no fio do paradoxo amoroso.

\section{REFERÊNCIAS}

ADORNO, Theodor. Educação e emancipação. Rio de Janeiro: Paz e Terra, 2000.

ARRUDA, Marcos. Educação para uma economia do amor - educação da práxis e economia solidária. Aparecida: Ideias e Letras, 2009.

BOÉTIE, Étienne de La. Discurso da servidão voluntária. São Paulo: Martin Claret, 2017.

BRANDÃO, Carlos Rodrigues. Nós, os humanos da vida ao homem, do homem à cultura. São Paulo: Cortez, 2016.

CARRILLO, Alfonso Torres. La educación popular - trayctória y actualidad. 2. ed. Bogotá: Editorial El Buho, 2012.

CALDART, Roseli Salete et al (org.). Dicionário da educação do campo. 2. ed. Rio de Janeiro: Expressão Popular/FIOCRUZ/E.P.S. Joaquim Venâncio, 2012.

CLASTRES, Pierre. Sociedade contra o Estado. São Paulo: UBU, 2017.
FÁVERO, Osmar (org.). Cultura popular e educação popular - memória dos anos sessenta. Rio de Janeiro: Graal, 1981.

FREIRE, Paulo. Pedagogia do oprimido. São Paulo: Instituto Paulo Freire, 2014.

MAUSS, Marcel. Sociologia e antropologia. São Paulo: EPU/EDUSP, 1974.

SANTOS, Boaventura de Souza. A crítica da razão indolente - contra o desperdício da experiência. 3. ed. São Paulo: Cortez, 2001.

SANTOS, Boaventura de Souza. Se Deus fosse um ativista dos direitos humanos. São Paulo: Cortez, 2014.

TADEU DA SILVA, Tomaz. Teoria cultural e educação - um vocabulário crítico. Belo Horizonte: Autêntica, 2000.

TOLSTOI, Liev. Liev Tolstoi - os últimos dias. São Paulo: Companhia das Letras, 2011.

TORRES CARRILLO, Alfonso. La Educación popular: trayctória y actualidad. 2. ed. Bogotá: El Buho, 2012.

Recebido em: 10/07/2019

Aprovado em: 10/09/2019

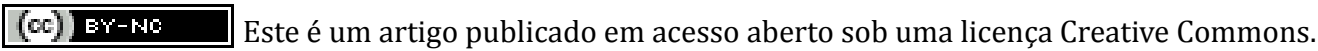

